\title{
KONTRIBUSI LINGKUNGAN KERJA DAN DISIPLIN KERJA GURU TERHADAP MUTU PEMBELAJARAN
}

\author{
Ipong Dekawati \\ Universitas Wiralodra, Jln. Ir. H. Juanda Km 3 Indramayu Jawa Barat Indonesia, \\ ipongdekawati@unwir.ac.id
}

Received April 24, 2018, reviewed July 30, 2018, published September 30, 2018

Citation: Dekawati, I. (2018). Kontribusi Lingkungan Kerja dan Disiplin Kerja Guru Terhadap Mutu Pembelajaran. Edum Journal, Vol 1, No 2, Hal 121-132, September 2018.

DOI: https://doi.org/10.31943/edumjournal.v1i2.478

\begin{abstract}
ABSTRAK
Penelitian ini bertujuan untuk mengetahui dan menganalisis kontribusi lingkungan kerja dan disiplin kerja guru terhadap mutu pembelajaran baik secara parsial maupun ganda. Metode penelitian yang digunakan adalah metode survey. Populasi terdiri dari guru sekolah dasar yang berjumlah 183 orang. Penentuan jumlah sampel menggunakan rumus Slovin, dengan hasil perhitungan terdapat 65 orang guru sebagai responden Pengambilan sampel dengan cara simple random sampling yang diambil dari setiap sekolah secara proporsional. Teknik analisis data menggunakan teknik analisis regresi. Uji signifikansi menggunakan uji-F. Hasil penelitian diperoleh, bahwa: (1) Terdapat kontribusi yang positif dan signifikan, lingkungan kerja terhadap mutu pembelajaran; (2) Terdapat kontribusi yang positif dan signifikan, disiplin kerja guru terhadap mutu pembelajaran (3) Terdapat kontribusi yang positif dan signifikan, lingkungan kerja dan disiplin kerja guru secara simultan terhadap mutu pembelajaran. Mengingat lingkungan kerja berpengaruh secara signifikan terhadap disiplin kerja guru, maka dalam rangka meningkatkan mutu pembelajaran, kepala sekolah perlu membantu para guru dalam memahami secara benar konsep lingkungan kerja dan disiplin kerja guru, serta konsep mutu pembelajaran. Hal ini dapat dilakukan dengan menambah wawasan dan pengetahuan dengan diikutsertakannya guru pada pelatihan profesi. Usahakan guru lebih intens mengikuti diskusi dan dinamika pada kelompok kerja guru (KKG).
\end{abstract}

Kata Kunci: Lingkungan Kerja, Disiplin Kerja Guru, Mutu Pembelajaran

\begin{abstract}
This study aims to find out and analyze the contribution of the work environment and work discipline of teachers to the quality of learning both partially and double. The research method used is the survey method. The population consisted of elementary school teachers totaling 183 people. Determination of the number of samples using the Slovin formula, with the results of the calculation there are 65 teachers as respondents sampling by simple random sampling taken from each school proportionally. The data analysis technique uses regression analysis techniques. Significance test using the F test. The results of the study were obtained, that: (1) There is a positive and significant contribution, the work environment towards the quality of learning; (2) There are positive and significant contributions, teacher work discipline towards learning quality (3) There are positive and significant contributions, the work environment and teacher work discipline simultaneously on the quality of learning. Given the work environment has a significant influence on teacher work discipline, so in order to improve the quality of learning, principals need to help teachers understand correctly the concept of work environment and teacher work discipline, as well as the concept of quality learning. This can be done by adding insight and knowledge with the inclusion of teachers in professional training. Try the teacher to be more intense following the discussion and dynamics in the teacher working group (KKG).
\end{abstract}

Keywords: Work Environment, Teacher's Work Discipline, Learning Quality 


\section{PENDAHULUAN}

Mutu pembelajaran berkaitan erat dengan lingkungan kerja dan disiplin guru dalam mengajar (Badawi, 2014). Lingkungan kerja, disiplin kerja, motivasi kerja bisa berimplikasi dengan kinerja guru dalam mengajar (Badawi, 2014). Oleh karena itu, lingkungan kerja, disiplin merupakan hal yang penting untuk meningkatkan kualitas pembelajaran (Guerriero, 2013). Lingkungan kerja merupakan salah satu faktor eksternal yang sangat berpengaruh dalam menunjang hasil kerja yang maksimal dalam setiap pekerjaan(Eliyanto, 2018). Triguno (2004:28) mengatakan bahwa lingkungan kerja yang partisipatif memungkinkan setiap sumber daya manusia mengondisikan diri agar apa yang menjadi sikap kerja berkelompok kemudian benar-benar menjadi perilaku kelompoknya. Untuk mengukur kondisi lingkungan kerja digunakan dimensi: (1) Lingkungan fisik dan (2) Lingkungan non fisik (Sedarmariyanti, 2009).

Selain itu, berdasarkan Peraturan Menteri Pendayagunaan Aparatur Negara Nomor: PER/87/M.PAN/8/ 2005 dijelaskan bahwa disiplin adalah sikap mental sumber daya manusia aparatur negara yang tercermin dalam perbuatan dan perilaku pribadi atau kelompok, berupa kepatuhan dan ketaatan terhadap aturan kerja, hukum dan norma kehidupan bermasyarakat, berbangsa, dan bernegara yang dilakukan secara sadar (Permenpan, 2005). Disiplin kerja merupakan perwujudan nilai-nilai budaya yang diyakini dan dijalankan oleh seluruh aparatur pemerintah dalam mencapai visi dan misi yang telah ditetapkan masing-masing lembaga/instansi (Muflihin, 2016). Berdasarkan uraian di atas dapat disimpulkan bahwa disiplin kerja adalah sikap mental yang terbentuk melalui proses tingkah laku untuk perorangan maupun kelompok dalam bentuk kesadaran dan kesediaan guru untuk menghargai, patuh dan taat pada peraturan-peraturan yang berlaku serta mau menerima sanksi atas tindakan yang dilakukan untuk memperteguh pedoman-pedoman yang berlaku di sekolah(Herawati, 2017). Dengan kata lain, dalam konteks keguruan disiplin mengarah pada kegiatan yang mendidik guru untuk patuh terhadap aturanaturan sekolah.

Seacara keseluruhan proses pendidikan di sekolah, pembelajaran merupakan aktivitas yang paling utama (Surya 2004:7). Proses interaksi antara pendidik dan peserta didik menjadi sangat penting dalam pembelajaran karena tanpa adanya interaksi edukatif poses pembelajaran tidak akan efektif (Hurst et al., 2013). Peran guru tentu saja bukan hanya sebagai sumber belajar, tetapi sebagai pembimbing dan pelayan 
siswa sebab pembelajaran sebagai proses belajar dibangun oleh guru untuk mengembangkan kreativitas berpikir yang dapat meningkatkan kemampuan berpikir siswa, serta dapat meningkatkan kemampuan mengkonstruksi pengetahuan baru sebagai upaya meningkatkan penguasaan yang baik terhadap materi pelajaran (Hurst et al., 2013). Sa'ud (2010:124) memaparkan bahwa pembelajaran merupakan serangkaian kegiatan yan dirancang untuk memungkinkan terjadinya proses belajar pada siswa. Oleh karena itu, pembelajaran sebagai suatu proses harus dirancang, dikembangkan dan dikelola secra kreatif, dinamis, dengan menerapkan pendekatan mutu untuk menciptakan suasana dan proses pembelajaran yang kondusif bagi siswa (Kadir Fatimah St., 2014).

Mutu pembelajaran merupakan ukuran kesesuaian antara harapan stakeholder pendidikan dengan hasil yang diberikan oleh sekolah yang terwujud dalam profil lulusan sekolah (Cepi Triatna, dkk., 2009:30). Sedangkan Tampubolon (2001:87) menegaskan bahwa pembelajaran bermutu sebagai, "proses dan produksi dan penyajian jasa pendidikan yang menyebabkan berbagai kemampuan yang sesuai dengan kebutuhan terus bertumbuh dalam diri siswa atau pembelajar. Karena itu, yang diutamakan dalam pembelajaran yang bermutu yang dapat menumbuhkan keemandirian dalam diri pembelajar, kecerdasan inelektual, kecerdesan emosional, dan keterampilan motoris.

\section{METODE PENELITIAN}

Penelitian ini dilaksanakan pada sekolah dasar negeri di Kecamatan Cisitu, Kabupaten Sumedang. Metode penelitian yang digunakan adalah metode survey. Populasi terdiri dari guru sekolah dasar yang berjumlah 183 orang. Penentuan jumlah sampel menggunakan rumus Slovin, dengan hasil perhitungan terdapat 65 orang guru sebagai responden Pengambilan sampel dengan cara simple random sampling yang diambil dari setiap sekolah secara proporsional. Teknik analisis data menggunakan teknik analisis regresi. Uji signifikansi menggunakan uji-F dengan bantuan SPSS.

\section{HASIL PENELITIAN DAN PEMBAHASAN}

\section{Kontribusi Lingkungan Kerja terhadap}

\section{Mutu Pembelajaran}

Untuk mengetahui besaran kontribusi lingkungan kerja $\left(\mathrm{X}_{1}\right)$ secara individual (parsial) terhadap mutu pembelajaran (Y) dapat dilihat dari nilai $\mathrm{t}$ pada tabel Coefficients dibawah ini dengan kriteria pengujian jika tingkat signifikansi lebih kecil dari 0,05, maka hipotesis diterima. 
Adapun hasil pengujian hipotesis tersebut

adalah sebagai berikut:

Tabel 1 Koefisien (t) Variabel $X_{1}$ terhadap $Y$

Coefficients $^{\mathrm{a}}$

\begin{tabular}{|c|c|c|c|c|c|}
\hline \multirow[b]{2}{*}{ Model } & \multicolumn{2}{|c|}{$\begin{array}{l}\text { Unstandardized } \\
\text { Coefficients }\end{array}$} & \multirow{2}{*}{\begin{tabular}{|c|}
$\begin{array}{c}\text { Standardized } \\
\text { Coefficients }\end{array}$ \\
Beta \\
\end{tabular}} & \multirow[b]{2}{*}{$\mathrm{t}$} & \multirow[b]{2}{*}{ Sig. } \\
\hline & $\mathrm{B}$ & Std. Error & & & \\
\hline $1 \quad$ (Constant) & 18,621 & 5,646 & & 3,298 &, 002 \\
\hline Lingkungan_Kerja_X $\mathrm{X}_{1}$ & ,596 & ,127 & ,508 & 4,681 &, 000 \\
\hline
\end{tabular}

a. Dependent Variable: Mutu_Pembelajaran_Y

Berdasarkan tabel hasil uji-t berdistribusi signifikan. Hal tersebut diperoleh bahwa nilai $t_{\text {hitung }}$ variabel berarti lingkungan kerja $\left(X_{1}\right)$ secara lingkungan kerja $\left(\mathrm{X}_{1}\right)$ memiliki nilai parsial berkontribusi terhadap mutu sebesar $p$-value $0,002<0,05$ artinya pembelajaran $(\mathrm{Y})$.

Tabel 2 Signifikansi Kontribusi Variabel $\mathrm{X}_{1}$ terhadap Y

ANOVA ${ }^{\mathrm{a}}$

\begin{tabular}{|cl|r|r|r|c|c|}
\hline Model & & Sum of Squares & \multicolumn{1}{c|}{ df } & Mean Square & F & Sig. \\
\hline 1 & Regression & 1211,096 & 1 & 1211,096 & 21,908 &, $000^{\mathrm{b}}$ \\
& Residual & 3482,750 & 63 & 55,282 & & \\
& Total & 4693,846 & 64 & & & \\
\hline
\end{tabular}

a. Dependent Variable: Mutu_Pembelajaran_Y

b. Predictors: (Constant), Lingkungan_Kerja_ $X_{1}$

Berdasarkan tabel hasil uji anova atau F test sebesar 21,908 dan nilai signifikansi $0,000<0,05$. Dengan demikian $\mathrm{H}_{\mathrm{o}}$ ditolak artinya kontribusi lingkungan kerja terhadap mutu pembelajaran adalah signifikan. Selanjutnya untuk mengetahui besaran kontribusi lingkungan kerja terhadap mutu pembelajaran dapat dilihat dari hasil perhitungan koefesien determinasi pada tabel dibawah ini.

Tabel 3 Besaran Kontribusi Variabel $X_{1}$ Terhadap Y

Model Summary

\begin{tabular}{|c|r|r|r|r|}
\hline Model & \multicolumn{1}{|c|}{$\mathrm{R}$} & R Square & $\begin{array}{c}\text { Adjusted R } \\
\text { Square }\end{array}$ & $\begin{array}{c}\text { Std. Error of } \\
\text { the Estimate }\end{array}$ \\
\hline 1 &, $508^{\mathrm{a}}$ &, 258 &, 246 & 7,435 \\
\hline
\end{tabular}

a. Predictors: (Constant), Lingkungan_Kerjai_X

Dari tabel di atas terlihat bahwa $R$ Square variabel lingkungan kerja berkontribusi sebesar 0,258, hal ini berarti bahwa sebesar 25,8\% terhadap mutu 
pembelajaran, sedangkan sisanya $74,2 \%$ dipengaruhi oleh faktor lain yang tidak diteliti.

\section{Kontribusi Disiplin Kerja Guru}

Terhadap Mutu Pembelajaran

Untuk mengetahui besaran kontribusi disiplin kerja guru $\left(\mathrm{X}_{2}\right)$ secara individual (parsial) terhadap mutu pembelajaran (Y) dapat dilihat dari nilai $\mathrm{t}$ pada tabel Coefficients dibawah ini dengan kriteria pengujian jika tingkat signifikansi lebih kecil dari 0,05 .

Tabel 4 Koefisien ( $t$ ) Variabel $X_{2}$ terhadap $Y$

Coefficients $^{\text {a }}$

\begin{tabular}{|c|c|c|c|c|c|}
\hline \multirow[b]{2}{*}{ Model } & \multicolumn{2}{|c|}{$\begin{array}{l}\text { Unstandardized } \\
\text { Coefficients }\end{array}$} & \multirow{2}{*}{$\begin{array}{c}\text { Standardized } \\
\text { Coefficients } \\
\text { Beta }\end{array}$} & \multirow[b]{2}{*}{ t } & \multirow[b]{2}{*}{ Sig. } \\
\hline & $\mathrm{B}$ & Std. Error & & & \\
\hline $1 \quad$ (Constant) & 22,290 & 4,676 & & 4,767 & ,000 \\
\hline Disiplin_Kerja_Guru_X ${ }_{2}$ &, 500 & ,102 &, 524 & 4,885 &, 000 \\
\hline
\end{tabular}

a. Dependent Variable: Mutu_Pembelajaran_Y

Berdasarkan tabel hasil uji $\mathrm{t}$ signifikan. Dengan demikian disiplin diperoleh bahwa nilai thitung variabel kerja guru $\left(\mathrm{X}_{2}\right)$ secara parsial disiplin kerja guru $\left(\mathrm{X}_{2}\right)$ memiliki nilai berkontribusi terhadap mutu sebesar $p$-value $0,000<0,05$ artinya pembelajaran $(\mathrm{Y})$.

Tabel 5 Signifikansi Kontribusi Variabel $X_{2}$ terhadap $Y$

ANOVA $^{\mathrm{a}}$

\begin{tabular}{|c|c|c|c|c|c|c|}
\hline & Sum of Squares & $\mathrm{df}$ & Mean Square & $\mathrm{F}$ & Sig. \\
\hline \multirow{2}{*}{1} & Regression & 1289,362 & 1 & 1289,362 & 23,860 &, $000^{\mathrm{b}}$ \\
\hline & Residual & 3404,485 & 63 & 54,039 & & \\
\hline & Total & 4693,846 & 64 & & & \\
\hline
\end{tabular}

a. Dependent Variable: Mutu_Pembelajaran_Y

b. Predictors: (Constant), Disiplin_Kerja_Guru_X $\mathrm{X}_{2}$

Berdasarkan tabel hasil uji anova atau F test didapat $\mathrm{F}_{\text {hitung }}$ sebesar 23,860 dan signifikansi $0,000<0,05$ sehingga $\mathrm{H}_{\mathrm{o}}$ ditolak artinya kontribusi disiplin kerja guru terhadap mutu pembelajaran adalah signifikan. Selanjutnya untuk mengetahui besaran pengaruh disiplin kerja guru terhadap mutu pembelajaran dapat dilihat dari hasil perhitungan koefesien determinasi pada tabel dibawah ini. 
Tabel 6 Besaran Kontribusi Variabel $X_{2}$ terhadap $Y$

Model Summary

\begin{tabular}{|c|c|r|r|r|}
\hline Model & R & R Square & \multicolumn{1}{c|}{$\begin{array}{c}\text { Adjusted R } \\
\text { Square }\end{array}$} & $\begin{array}{c}\text { Std. Error of the } \\
\text { Estimate }\end{array}$ \\
\hline 1 &, $524^{\mathrm{a}}$ &, 275 &, 263 & 7,351 \\
\hline
\end{tabular}

a. Predictors: (Constant), Disiplin_Kerja_Guru_X 2

Dari tabel di atas terlihat bahwa $R$ Square sebesar 0,275, hal ini berarti bahwa disiplin kerja guru mempengaruhi mutu pembelajaran sebesar 27,5\%, sedangkan sisanya $72,5 \%$ dipengaruhi oleh faktor lain yang tidak diteliti.

\section{Kontribusi Lingkungan Kerja dan \\ Displin Guru Terhadap Mutu \\ Pembelajaran}

Tabel 7 Koefisein (t) Variabel $X_{1}$ dan $X_{2}$ terhadap $Y$

Coefficients $^{\mathrm{a}}$

\begin{tabular}{|c|c|c|c|c|c|}
\hline \multirow[b]{2}{*}{ Model } & \multicolumn{2}{|c|}{$\begin{array}{c}\text { Unstandardized } \\
\text { Coefficients }\end{array}$} & \multirow{2}{*}{$\begin{array}{c}\begin{array}{c}\text { Standardized } \\
\text { Coefficients }\end{array} \\
\text { Beta }\end{array}$} & \multirow[b]{2}{*}{$\mathrm{t}$} & \multirow[b]{2}{*}{ Sig. } \\
\hline & $\mathrm{B}$ & Std. Error & & & \\
\hline $1 \quad$ (Constant) & 4,583 & 5,839 & &, 785 &, 435 \\
\hline Lingkungan Kerja_ $\mathrm{X}_{1}$ & ,489 &, 114 &, 417 & 4,298 &, 000 \\
\hline Disiplin_Kerja_Guru_X ${ }_{2}$ & ,417 & ,093 & 437 & 4,508 &, 000 \\
\hline
\end{tabular}

a. Dependent Variable: Mutu_Pembelajaran_Y

Berdasarkan tabel hasil uji $t$ diperoleh bahwa nilai $t_{\text {hitung }}$ variabel lingkungan kerja $\left(\mathrm{X}_{1}\right)$ dan disiplin kerja guru $\left(\mathrm{X}_{2}\right)$ secara bersama-sama (simultan) memiliki nilai sebesar $p$-value $0,000<0,05$ artinya signifikan. Dengan demikian lingkungan kerja $\left(\mathrm{X}_{1}\right)$ dan disiplin kerja guru $\left(\mathrm{X}_{2}\right)$ secara bersamasama (simultan) berkontribusi terhadap mutu pembelajaran (Y). Untuk mengetahui persamaan regresi dapat
Untuk mengetahui besaran kontribusi lingkungan kerja $\left(\mathrm{X}_{1}\right)$ dan disiplin kerja guru secara bersama-sama (simultan) terhadap mutu pembelajaran (Y) dapat dilihat dari nilai t pada tabel Coefficients dibawah ini dengan kriteria pengujian jika tingkat signifikansi lebih kecil dari 0,05 . 
Tabel 8 Signifikansi Kontribusi Variabel $X_{1}$ dan $X_{2}$ terhadap $Y$

\begin{tabular}{|c|c|c|c|c|c|}
\hline \multicolumn{6}{|c|}{ ANOVA $^{\mathrm{a}}$} \\
\hline Model & Sum of Squares & $\mathrm{df}$ & Mean Square & $\mathrm{F}$ & Sig. \\
\hline 1 Regression & 2070,768 & 2 & 1035,384 & 24,473 &, $000^{b}$ \\
\hline Residual & 2623,078 & 62 & 42,308 & & \\
\hline Total & 4693,846 & 64 & & & \\
\hline
\end{tabular}

a. Dependent Variable: Mutu_Pembelajaran_Y

b. Predictors: (Constant), Disiplin_Kerja_Guru_X ${ }_{2}$, Lingkungan_Kerja_X $X_{1}$

Berdasarkan tabel hasil uji anova atau $\mathrm{F}$ test didapat $\mathrm{F}_{\text {hitung }}$ sebesar 24,473 dan signifikansi $0,000<0,05$ sehingga $\mathrm{H}_{\mathrm{o}}$ ditolak artinya kontribusi lingkungan kerja dan disiplin kerja guru secara simultan terhadap etos kerja guru adalah signifikan.
Selanjutnya untuk mengetahui besaran pengaruh lingkungan kerja dan disiplin kerja guru secara bersama-sama (simultan) terhadap mutu pembelajaran dapat dilihat dari hasil perhitungan koefesien determinasi pada tabel dibawah ini:

\section{Tabel 9 Besaran Kontribusi Variabel $X_{1}$ dan $X_{2}$ terhadap $Y$}

Model Summary

\begin{tabular}{|c|r|r|r|r|}
\hline Model & \multicolumn{1}{|c|}{$\mathrm{R}$} & R Square & Adjusted R Square & Std. Error of the Estimate \\
\hline 1 &, $664^{\mathrm{a}}$ &, 441 &, 423 & 6,504 \\
\hline
\end{tabular}

a. Predictors: (Constant), Disiplin_Kerja_Guru_X ${ }_{2}$,Lingkungan_Kerja_X ${ }_{1}$

Dari tabel di atas terlihat bahwa $R$ Square sebesar 0,441, hal ini berarti bahwa variabel lingkungan kerja dan disiplin kerja guru secara bersama-sama (simultan) berkontribusi sebesar $44,1 \%$ terhadap mutu pembelajaran, sedangkan sisanya $55,9 \%$ dipengaruhi faktor lain yang tidak diteliti.

\section{Pembahasan}

Permasalahan yang ingin dijawab dalam penelitian ini adalah adakah pengaruh lingkungan kerja terhadap mutu pembelajaran. Secara empirik, hasil penelitian ini menginformasikan: (1) terdapat pengaruh yang signifikan lingkungan kerja terhadap mutu pembelajaran, serta (2) besarnya pengaruh lingkungan kerja terhadap mutu pembelajaran ditunjukkan oleh hasil penelitian bahwa lingkungan kerja yang terdiri dari dimensi: (1) lingkungan fisik, dan (2) lingkungan non fisik (Sedarmayanti, 2009), membawa implikasi yang signifikan terhadap mutu pembelajaran yang meliputi dimensi: (1) mutu input; (2) mutu proses; (3) mutu 
output (Cepi Triatna dkk, 2009). Melalui

hasil penelitian yang telah dipaparkan di atas, diketahui bahwa hasil penelitian ini sesuai dengan pendapat Robbins (1996:181) bahwa tingkah laku manusia itu timbul karena adanya rangsangan, tidak ada tingkah laku yang terjadi tanpa adanya rangsangan. Hal ini pun didukung oleh hasil penelitian Dewi Andriani (2010:983), yang menyimpulkan lingkungan kerja bepengaruh positif terhadap disiplin kerja karyawan.

Namun demikian mutu pembelajaran ini tidak hanya dipengaruhi oleh lingkungan kerja saja, ada faktor lain (epsilon), selain disiplin kerja guru, yang juga berpengaruh, yang tidak dikaji dalam penelitian ini. Dengan demikian, hasil penelitian ini mengindikasikan bahwa semakin bagus lingkungan kerja yang dirasakan oleh guru, maka akan diikuti oleh semakin tingginya mutu pembelajaran. Berdasarkan temuan empirik yang menunjukkan adanya kontribusi yang signifikan lingkungan kerja dengan mutu pembelajaran yang besarnya mencapai $25,8 \%$, sementara sisanya dipengaruhi oleh variabel lain, selain variabel disiplin kerja guru, yang tidak dikaji dalam penelitian ini (epsilon).

Selanjutnya permasalahan yang ingin dijawab dalam penelitian ini adalah adakah pengaruh disiplin kerja guru terhadap mutu pembelajaran. Secara empirik, hasil penelitian ini menginformasikan: (1) terdapat pengaruh yang signifikan disiplin kerja guru terhadap mutu pembelajaran (2) besarnya pengaruh disiplin kerja guru terhadap mutu pembelajaran ditunjukkan oleh hasil penelitian bahwa tingginya disiplin kerja guru yang terdiri dari dimensi: (1) disiplin terhadap tugas kedinasan, (2) disiplin terhadap waktu, (3) disiplin terhadap suasana kerja, (4) disiplin di dalam melayani siswa dan orang tua siswa, (5) disiplin terhadap sikap dan tingkah laku (Aritonang, 2005), membawa implikasi yang signifikan terhadap mutu pembelajaran yang meliputi dimensi: (1) mutu input; (2) mutu proses; (3) mutu output (Cepi Triatna dkk, 2009).

Melalui hasil penelitian yang telah dipaparkan di atas, diketahui bahwa hasil penelitian ini sesuai dengan pendapat Sutrisno (2009) yang menyatakan dengan disiplin kerja pegawai dapat melaksanakan tugasnya dengan penuh kesadaran serta dapat mengembangkan tenaga dan pikirannya semaksimal mungkin demi terwujudnya tujuan organisasi. Hasil penelitian ini pun diperkuat oleh Darwis A Sulaiman (1979:128) yang menyatakan bahwa,"guru memegang peranan penting 
keberhasilan pendidikan di sekolah, karena guru tidak hanya panutan bagi murid-muridnya, tetapi juga merupakan contoh teladan bagi masyarakat lainnya. Dengan demikian jelaslah bahwa jika guru di suatu sekolah disiplin, maka personil lainnya terutama muridmuridnya akan disiplin juga".

Namun demikian mutu pembelajaran ini tidak hanya dipengaruhi oleh disiplin kerja guru saja, ada faktor lain (epsilon), selain lingkungan kerja yang juga berpengaruh, yang tidak dikaji dalam penelitian ini. Dengan demikian, hasil penelitian ini mengindikasikan bahwa semakin bagus kondisi disiplin kerja guru yang dirasakan guru, maka akan diikuti oleh semakin tingginya mutu pembelajaran. Berdasarkan temuan empirik yang menunjukkan adanya kontribusi yang signifikan disiplin kerja guru terhadap mutu pembelajaran, maka hasil penelitian ini memberikan beberapa informasi, di antaranya: (1) Kondisi disiplin kerja guru memberikan pengaruh yang berarti terhadap mutu pembelajaran, (2) Salah satu cara untuk meningkatkan mutu pembelajaran adalah dengan meningkatkan disiplin kerja guru, serta (3) Kontribusi yang diberikan oleh pengaruh disiplin kerja guru terhadap mutu pembelajaran adalah sebesar $27,5 \%$, sementara sisanya dipengaruhi oleh variabel lain, selain variabel lingkungan kerja, yang tidak dikaji dalam penelitian ini (epsilon).

Terakhir, permasalahan yang ingin dijawab dalam penelitian ini adalah adakah pengaruh lingkungan kerja dan disiplin kerja guru secara simultan terhadap mutu pembelajaran.Secara empirik, hasil penelitian ini menginformasikan: (1) terdapat pengaruh yang signifikan lingkungan kerja dan disiplin kerja guru secara simultan terhadap mutu pembelajaran, serta (2) besarnya pengaruh lingkungan kerja dan disiplin kerja guru secara simultan terhadap mutu pembelajaran ditunjukkan oleh hasil penelitian bahwa lingkungan kerja yang terdiri dari dimensi: (1) lingkungan fisik, dan (2) lingkungan non fisik (Sedarmayanti, 2009), serta disiplin kerja dengan dimensi: (1) disiplin terhadap tugas kedinasan, (2) disiplin terhadap waktu, (3) disiplin terhadap suasana kerja, (4) disiplin di dalam melayani siswa dan orang tua siswa, (5) disiplin terhadap sikap dan tingkah laku (Aritonang, 2005), membawa implikasi yang signifikan terhadap mutu pembelajaran yang meliputi dimensi: (1) mutu input; (2) mutu proses; (3) mutu output (Cepi Triatna dkk, 2009).

Namun demikian mutu pembelajaran, selain dipengaruhi oleh 
kedua variabel di atas, ada faktor lain (epsilon), yang juga berkontribusi, yang tidak dikaji dalam penelitian ini. Dengan demikian, hasil penelitian ini mengindikasikan bahwa semakin bagus kondisi lingkungan kerja dan disiplin kerja guru secara simultan, maka akan diikuti oleh semakin tingginya mutu pembelajaran. Hal ini dapat diterangkan oleh persamaan regresi $\mathrm{Y}=4,583+$ $0,489 X_{1}+0,417 X_{2}$. Dengan persamaan regresi tersebut dapat diinterpretasikan bahwa jika lingkungan kerja $\left(\mathrm{X}_{1}\right)$, dan disiplin kerja guru $\left(\mathrm{X}_{2}\right)$ dan mutu pembelajaran (Y) diukur dengan instrumen yang dikembangkan dalam penelitian ini, maka setiap perubahan skor lingkungan kerja, dan disiplin kerja guru secara simultan sebesar satu satuan dapat diestimasikan skor mutu pembelajaran akan berubah 0,489 dan 0,417 satuan pada arah yang sama. Dengan didasari hasil penelitian yang telah dilakukan, maka terbukti bahwa terdapat pengaruh lingkungan kerja terhadap mutu pembelajaran pada sesuai dengan pendapat Cruickshank (1990) bahwa faktor-faktor yang mempengaruhi belajar siswa dapat dibedakan menjadi empat variabel, yaitu variabel guru; variabel konteks (berupa siswa, lingkungan sekolah, dan kelas), variabel proses, dan variabel produk.

\section{KESIMPULAN}

Berdasarkan temuan empirik yang menunjukkan adanya pengaruh yang signifikan lingkungan kerja dan disiplin kerja guru terhadap mutu pembelajaran, maka hasil penelitian ini memberikan beberapa informasi, di antaranya: (1) Kondisi lingkungan kerja dan disiplin kerja guru secara simultan memberikan kontribusi yang berarti terhadap mutu pembelajaran, (2) Salah satu cara untuk meningkatkan mutu pembelajaran adalah dengan meningkatkan lingkungan kerja dan disiplin kerja guru. (3) Kontribusi yang diberikan oleh lingkungan kerja dan disiplin kerja guru secara bersama-sama (simultan) terhadap mutu pembelajaran adalah sebesar $44,1 \%$, sementara sisanya dipengaruhi oleh variabel lain, yang tidak dikaji dalam penelitian ini (epsilon).

\section{DAFTAR PUSTAKA}

Aritonang, K.T. (2005). Kompensasi Kerja, Disiplin Kerja Guru dan Kinerja Guru. Jurnal Pendidikan Penabur. No. 04, 1-16.

Badawi, A. (2014). Pengaruh Lingkungan Kerja, Disiplin Kerja, dan Motivasi Kerja terhadap Kepuasan Kerja serta Implikasinya pada Kinerja Guru. Kontigensi, 2(1), 1-10.

Cepi Triatna, S \& Koswara, D. (2009). Studi Dampak Program Sertifikasi Guru Terhadap Peningkatan Profesionalisme dan Mutu di Jawa Barat. Penelitian Hibah 
Fundamental Jurusan Administrasi Pendidikan UPI. Bandung: Tidak diterbitkan.

Cruickshank. (1990). Research that Informs Teachers and Teacher educatiors. Bloomington: Phi Delta Kappa Educational Foundation.

Darwis A. S. (1979). Teori dan Praktek Pengajaran. Semarang: IKIP Semarang Press.

Eliyanto. (2018). Pengaruh Motivasi Kerja dan Lingkungan Kerja Terhadap Kinerja Guru SMA Muhammadiyah di Kabupaten Kebumen. Jurnal Pendidikan Madrasah, 3(1), 169-181.

Guerriero, S. (2013). Teachers' pedagogical knowledge and the teaching profession: Background report and project objectives. Organisation for Economic Cooperation and Development (OECD).

https://doi.org/10.1007/s10086-0101140-3

Herawati, M. (2017). Journal of Education and Development. Research and Development Journal of Education, 4(2), 63-74.

Hurst, B., Wallace, R., Nixon, S. B., Hurst, B., Wallace, R., \& Nixon, S. B. (2013). Reading Horizons The Impact of Social Interaction on Student Learning The Impact of Social Interaction on Student Learning. Reading Horizons, 52(4).

Kadir Fatimah St. (2014). Keterampilan Mengelola Kelas Dan Implementasinya Dalam Proses Pembelajaran. Jurnal Al-Ta'dib, 7(2), 16-36.

Muflihin, H. M. (2016). Manajemen
Disiplin Kerja: Perspektif Tenaga Pendidik dan Kependidikan. Lentera Pendidikan, 19(1), 66-75.

Permenpan. Peraturan Menteri Pendayagunaan Aparatur Negara

Nomor: PER/87/M.PAN/8/2005

Tentang Pedoman Peningkatan Pelaksanaan Efesiensi Penghematan dan Disiplin Kerja (2005).

Sa'ud, Udin Syaefuddin. (2010). Inovasi Pendidikan. Bandung: Alfabeta.

Surya, M. (2004). Psikologi Pembelajaran dan Pengajaran. Bandung: Pustaka Bani. Quraisy.

Tampubolon, Daulat. (2001). Perguruan Tinggi Bermutu. Jakarta : PT. Gramedia.

Triguno. (2000). Budaya Kerja: Menciptakan Lingkungan yang Kondusive untuk Meningkatkan Produktivitas Kerja. Jakarta: PT. Golden Terayon Press. 